\title{
Determinants of Compensation: A Study of Pay, Performance, and Gender Differences for Fundraising Professionals
}

\author{
Debra J. Mesch, Patrick M. Rooney
}

This study examines the determinants of compensation for fundraising professionals by addressing the following research questions: (1) Is there a significant pay-performance relationship? (2) What are the factors that affect bonus and salary? (3) Is there a gender-pay gap for individuals who are in the role of fundraisers? Data were collected over a four-year period from a national sample of fundraising professionals employed across all industry classifications. Amount of money raised was the primary performance variable of interest. Bivariate tests for differences between males and females, as well as two-stage simultaneous regressions, were used to determine the effects of fundraising performance on the pay of fundraisers. Results indicated a significant and positive pay-performance linkage across all fundraising positions, particularly for chief development officers, as well as a consistent gender-pay gap across fundraising positions.

A LTHOUGH THERE HAS BEEN some theoretical work on compensation in nonprofits (for example, Hallock, 2000; Ruhm and Borkoski, 2003; Steinberg, 1990; Weisbrod, 1988), we have little understanding of the actual determinants of compensation in nonprofits from an empirical point of view (Hallock, 2000). One reason for the lack of empirical testing is that given the constraints and characteristics of the nonprofit sector, examining pay is problematic (Hallock, 2000). However, without a body of research that specifically

Note: We thank our research assistants, Brian Denton and Yuan Ding, master's degree students in economics, for their assistance in the empirical analysis. We also thank an anonymous reviewer for the suggestion of using two-stage simultaneous regressions. Finally, we are indebted to Partha Deb of Hunter College for insights and suggestions in solving the technical problems associated with using instrumental variables and two-stage simultaneous regressions. 


Compensation
packages have
exploded for
many chief
executives in the
nonprofit sector.

focuses on compensation in the nonprofits, it is difficult to determine whether incentive systems that are found to be successful in the private sector will have their intended effects in the nonprofit arena.

There are several reasons that the lack of empirical research and validation of compensation systems in the nonprofit sector is troubling. First, compensation packages have exploded for many chief executives in the nonprofit sector (Schwinn and Wilhelm, 2003). Salaries paid in 2003 to the top executives of the nation's largest nonprofits rose by twice the inflation rate, and the salaries of CEOs of the largest charities and foundations more than doubled from 1997 to 2002 ; in fact, they received higher percentage raises than did their counterparts in the corporate world (Schwinn and Wilhelm, 2003). Second, although use of performance-based compensation plans is a relatively new practice in nonprofits, such practices are becoming more prevalent and are expected to increase in the future (Alvarado, 1996; Bailey and Risher, 1996; Deckop and Cirka, 2000). Some studies have found that 25 percent of nonprofits offer managers the opportunity to earn cash compensation-usually tied to achievement of performance measures (Rocco, 1991, 1992). Third, management pay in the nonprofit world is becoming more highly scrutinized. New legislation requires nonprofits to document how much they pay their top management as well as require that boards justify and outline the compensation determination process (Preston, 2004). "If the salaries are found to be higher than expected and higher than those found in similar charities," fines could be levied and boards could be required to return the amount overpaid (Hallock, 2002a, p. 378).

Our study uses compensation survey data from a large national membership association-the Association of Fundraising Professionals (AFP) - a professional society responsible for generating philanthropic support for a wide variety of nonprofits. Its mission is to advance philanthropy by enabling people and organizations to practice ethical and effective fundraising - activities that include education, training, mentoring, research, credentialing and advocacy.

Membership associations may be defined as "mutual benefit organizations, incorporated to serve their members' interests" (Tschirhart, 2006, p. 523), formally organized and usually not recompensed for their participation (Knoke, 1986). Although membership associations make up a significant component of the nonprofit sector-consisting of 33 percent of the nonprofits registered in the United States (Tschirhart, 2006) — there is a paucity of research on this sector and virtually no examination of executive pay in this type of nonprofit.

\section{Purpose of the Study}

The purpose of our study is to address the following research questions: (1) What are the significant determinants of compensation for 
individuals who are employed as fundraising professionals in nonprofits? More specifically, does performance have a significant effect on compensation for these professionals? (2) What are the key determinants of bonus and salary for these individuals? (3) Is there a gender-pay gap for individuals who are in the role of fundraisers for nonprofits?

First, we test to see whether there is a relationship between fundraiser performance and compensation. We selected fundraising professionals because of the implicit relationship between their role in the organization and performance (that is, "contributions raised") to better test the pay-performance relationship. Performance can be appropriately rewarded only if it can be accurately measured and directly related to employee efforts. Presumably we would expect to see a more direct linkage between job content or job responsibilities and performance for individuals who are in the role of fundraising rather than other types of positions in nonprofits. In fact, fundraising has been described as a profession that is mission driven, offering clear goals, advancement based on results, and work performance that is quantifiable (Tifft, 1992). In our study, we use "money raised," a quantifiable measure of performance that directly relates to the efforts of fundraisers and is a measure of success. Furthermore, fundraising professionals are unique to the nonprofit sector and traditionally not found in for-profit firms. Few studies have been conducted that look at determinants of compensation for these individuals.

Second, we disaggregate compensation into bonus and salary in order to examine the pay-performance relationship more fully. Is the pay-performance relationship for fundraisers significant for bonus, for salary, or both? Studies comparing for-profit and nonprofit organizations have found that nonprofits paid greater base salaries, lower bonuses, and lower total compensation than for-profits, ceteris paribus (Roomkin and Weisbrod, 1999; Weisbrod, 1983). However, for fundraisers, where the measure of performance is objective and measurable (as is primarily the case in for-profit firms), there may be a more contingent relationship between performance and bonus because it is a reliable way to reward achievement of goals. Unlike other pay-performance studies, under these conditions we may actually find a relationship between performance and bonuses.

It is important to note that there is nothing illegal about being paid for performance as a fundraiser-and, in fact, this may be a way to motivate employees to increase performance (Harrison, 1995). According to ethical guidelines, fundraisers are allowed to accept performance-based compensation (Sczudlo, 2003). Although we would expect to see a stronger relationship between pay and performance for fundraisers than perhaps other individuals, we need to bear in mind the ethical standards facing fundraisers in nonprofits and the importance of upholding the public trust. "In fact, nowhere is ethical behavior more essential, or its absence more damaging, than in philanthropic fundraising" (Sczudlo, 2003, p. 30). As such,

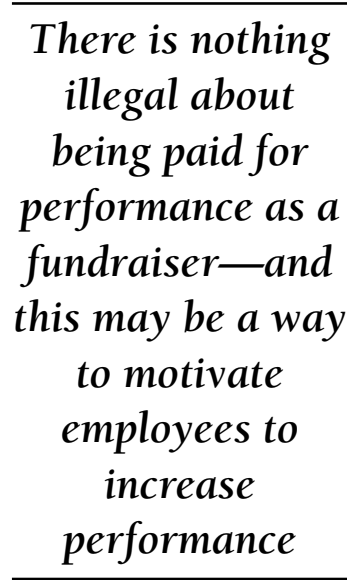


the pay-for-performance relationship for fundraisers may be somewhat suppressed, where a "commission" or percentage-based pay for performance is prohibited.

Third, we focus on issues of gender equity in the fundraising workforce. Over the past decade, there has been an increase in the memberships of the top three professional organizations representing fundraisers, to the point now where the majority of professionals are women (Conry, 1998). Furthermore, more women than men are entering this profession as paid employees where women occupy all fundraising job categories across all types of nonprofit organizations (Conry, 1998). Conry (1991) refers to this phenomenon as "the feminization of fundraising" and cautions that this could have negative implications on the salaries, prestige, and status of a previously male-dominated occupation in which fundraising is seen as "women's work."

Much research has been conducted on the gender-pay gap in the private sector (for example, Bertrand and Hallock, 2001; Blau and Ferber, 1992; Chauvin and Ash, 1994; Gerhart, 1990; Groshen, 1991; Harris, Gilbreath, and Sunday, 2002; Mohan and Ruggiero, 2003; Rose and Hartmann, 2004; Wood, Corcoran, and Courant, 1993), indicating that women are paid significantly less than men, even when controlling for the industry, firm size, occupation, human capital, performance, and organizational structural factors that are traditionally associated with pay differentials. Although the nonprofit sector is dominated by women, very little research addresses wage differences between men and women (Hallock, 2000; Steinberg and Jacobs, 1994). In our study, we investigate whether this finding persists in the nonprofit sector, in a profession where there is a quantifiable measure of performance as well as a preponderance of women recently entering the profession.

\section{Compensation in Nonprofit Organizations}

Much has been written regarding the theoretical reasons for differences between compensation in the for-profit and nonprofit sector and why compensation systems found in for-profit firms may not generalize to nonprofits (see Ballou and Weisbrod, 2003; Hallock, 2000; Leete, 2001; Preston, 1989; Steinberg, 1990; Weisbrod, 1986, 1988; Young and Steinberg, 1995 for discussion of this literature). A primary difference is that nonprofits operate under the "nondistribution constraint" (Hansmann, 1980), thereby prohibiting distribution of profits to owners, and thus restricting organizations as to the type of compensation practices as well as the form of compensation that can be offered to its managers and employees. Given the nondistribution constraint, "performance pay in nonprofits has historically not been very significant," even though nonprofits are not precluded legally from engaging in this practice (Hallock, 2000, p. 259). Several recent studies, however, have found a strong, positive link between 
the assets of a nonprofit and the pay of its top manager (for example, Brickley and Van Horn, 2002; Hallock, 2002a). Gray and Benson (2003) found that when resource efficiency was used as an indicator of performance, nonprofit executive compensation was based, at least in part, on organizational performance, although client satisfaction had no effect. A recent study by Carroll, Hughes, and Luksetich (2005) found a positive relationship between executive compensation and performance when performance was measured as revenue per dollar of noncompensation expenditure. However, this analysis revealed that compensation and performance were simultaneously determined.

The nondistribution constraint in the nonprofit sector leads to a "sorting" of managers among the two sectors where "managers with the least aversion to risk and the weakest preference for leading an organization that has goals other than profit maximization" are more attracted to the for-profit rather than the nonprofit sector (Roomkin and Weisbrod, 1999, p. 778). Given that the nondistribution constraint restricts managerial discretion-particularly regarding compensation decisions-managers, as well as other employees, may sort themselves according to the type of organization that they find most compatible with their preferences. That is, individuals may be willing to "donate" their paid labor to a nonprofit cause that they care about by accepting less compensation (Frank, 1996).

A second significant difference between compensation in the forprofit and nonprofit sectors has to do with the way in which performance is measured. Unlike for-profit firms where the bottom-line performance is focused on making a profit and demonstration of results, nonprofits conduct business in pursuit of a social mission, where ideal information on performance is often unobtainable, costly, abstract, and not easily quantified (Weisbrod, 1988). Finding appropriate performance metrics to satisfy stakeholders, as well as determining which performance indicators should be tied to pay, is much more difficult (Hallock, 2000; Handy and Katz, 1998; Steinberg, 1990). Consequently, nonprofit boards often rely on more indirect and imperfect measures of performance, such as activity or process measures (Weisbrod, 1988). As such, nonprofits must choose between rewarding what is easily measured-even though this may not reward the desired outcomes-incurring costs by devising better measures or by not rewarding performance at all (Weisbrod, 1988).

However, in comparison to other types of positions in nonprofits, fundraising actually is results oriented, and outcomes can be measured (Duronio and Loessin, 1991). This is not to imply that organizations providing fundraisers with specific goals are engaging in unethical behavior-or that they will be more ethical and productive if the focus is on process rather than on the results achieved. Instead, the role of fundraisers requires an understanding of the balance between "concern for results with concern for how results are achieved" (Durnio and Loessin, 1991, p. 129). In fact, fundraisers

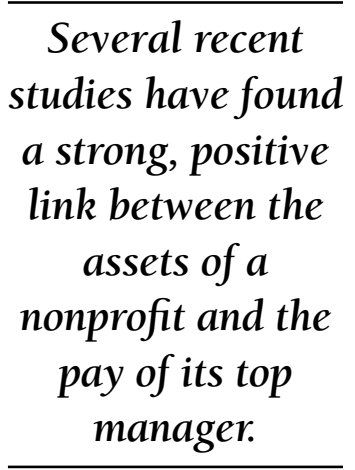




The pay gap
[between males
and females in
top positions] is
greatest among
the largest
nonprofits.

who do not have specific, measurable goals and are not judged by what they accomplish may leave more room for unethical behavior than if evaluated on actual performance (Duronio and Loessin, 1991). However, it has been suggested that "incentive contracts for fundraisers may lead to a perception among donors that their contributions are being diverted away from the organization's major purpose and toward fundraiser compensation" (Carroll, Hughes, and Luksetich, 2005, p. 20).

\section{Gender and Pay}

Research efforts over the past three decades "have attempted to disentangle factors that account for the gender-pay gap" (Renner, Rives, and Bowlin, 2002, p. 332), and a great deal of theoretical work has been developed in explaining the reasons that these differences occur (for example, Blau, 1998; Blau and Ferber, 1992; Blau, Ferber, and Winkler, 1998; Weichselbaumer, 2004). Reports in the popular press give an account of surveys that indicate senior female executives as well as other top positions of our nation's nonprofits are routinely paid less than men in similar jobs: as high as a 50 percent gender differential exists for CEOs (Lewin, 2001; Lipman, 2002). The pay gap is greatest among the largest nonprofits (Lipman, 2002; GuideStar, 2005), persisting even across comparable job titles and responsibilities (Williams, 2003), controlling for organization size (GuideStar, 2005).

Recent empirical research on nonprofits has found similar results. Although a few studies have found that CEO gender was not significantly related to compensation of nonprofits (for example, Oster, 1998; Preston, 1989), the majority of studies have found just the opposite (for example, Hallock, 2002b; Gibelman, 2000; Gray and Benson, 2003; Werner, Konopaske, and Gemeinhardt, 2000; Williams, 2003; Ye and Manzo, 2004). Given that the nonprofit labor force is dominated by women, these results are even more troubling. According to the Bureau of Labor Statistics, more than two-thirds of nonprofit workers are women, compared with about 43 percent of the employed civilian labor force as a whole (Johnston and Rudney, 1987).

\section{Methods}

In terms of fundraising professionals, Conry (1998) summarizes several surveys that conclude female fundraisers have not made equal progress in compensation rates. These findings indicate that (1) although overall salaries are climbing for fundraisers, women's pay consistently lags behind that of men, and (2) women holding senior management positions in fundraising are still a fraction of their overall numbers as a group. These surveys, however, did not control for the human capital factors traditionally associated with compensation. The purpose of our study is to test whether a pay gap exists, controlling for organizational and human capital variables. 


\section{Sample and Data}

A national cross-sectional sample consisting of 2,439 fundraising professionals across all subsectors of the nonprofit field was collected through the AFP's Compensation and Benefits Survey that was administered once a year for four years. The sample consists of professionals who are members of the AFP and are currently employed in fundraising roles in a nonprofit organization. AFP was founded in 1960 and has approximately twenty-six thousand members in 171 chapters throughout the world.

The respondents are employed in the following types of nonprofits: 27 percent are from education, 5 percent from religious organizations, 9 percent from social services, 23 percent from arts and culture, 20 percent from health, and 11 percent are other; 68 percent are employed full time, 26 percent more than half time, and 2 percent less than half time; 43 percent are in positions as chief development officer (CDO), 23 percent deputy director, 20 percent staff, and 8 percent consultant. Mean age of respondents is forty-four; 69 percent of the sample is female, 94 percent white; 24 percent have a bachelor's degree, and 49 percent have postgraduate education. The average number of years employed as a fundraising professional is 14. Most of the respondents (58 percent) have one or more professional certificates. The average salary in the sample was $\$ 70,000$ and ranged as high as $\$ 850,000$. Bonuses tended to be a small share of compensation, averaging only 1.2 percent, but they went as high as 25 percent. Most (81 percent) responding organizations did not pay a bonus. While the average fundraising experience overall is 14 years, the average with the current particular nonprofit is only 4.5 years, suggesting considerable churning among fundraisers. This turnover may be a way that fundraisers, particularly women, seek pay equity given that pay raises occur with job changes. While 24 percent have a contract, only 3 percent received a signing bonus at the time of hire.

Four years of survey data were obtained for the period from 2002 to 2005 from AFP. Each year, AFP conducts a compensation and benefits survey of all its members. The survey asks questions about contributions raised, the organization's operating budget, bonus and salary information, and demographic information.

\section{Dependent Variable}

The dependent variable was compensation. CEO compensation was operationalized in two ways: base salary and bonus only (over a twelve-month period). These measures represent total cash provided to the incumbent and are widely used in the executive compensation literature. In theory, base salary is used to represent a fixed component of total compensation, whereas bonuses vary according to some measure of performance (Gomez-Mejia, 1994). To adjust for the wide range of salaries and more closely approximate a normal distribution, we use logSalary as the measure of salary in the analysis. Bonus is expressed as the percentage of total compensation.

\section{The dependent variable was compensation.}




\section{Independent Variable}

Performance was operationalized as the amount of money raised by the organization in contributed gifts from all sources in a particular fiscal year. We use logMoney in the analysis.

\section{Control Variables}

The control variables were as follows:

Type of organization. Organizations were coded as (1) educational, (2) religious, (3) consulting firm, partnership, or sole entrepreneurship, (4) health, (5) social service, (6) arts and culture, (7) other.

Geographic scope. This was coded as (1) international, (2) national, (3) state, provincial, regional, or (4) local.

Organizational size. Organizational size was (1) operating budget coded as the $\log$ (Budget) for the fiscal year and (2) number of fundraising support staff.

Region. The location of the organization was coded as (1) United States or (2) other.

Size of the metropolitan area was a categorical variable indicating population of the metropolitan area, coded as (1) 0 to 500,000, (2) 500,000 to 1 million, (3) 1 million to 3 million, or (4) more than 3 million.

Position in the organization was coded as (1) chief development officer, (2) deputy director, (3) staff, or (4) consultant.

Experience was coded as the number of years employed as a fundraising professional as well as experience squared, and number of years with current employer.

Contract was whether the fundraising professional was under an employment contract.

Signing bonus was whether the fundraising professional had a signing bonus when hired.

Recruiter was whether the fundraising professional worked with an executive recruiter to secure their position.

Age was coded as age and age squared.

Gender was coded as $1=$ female.

Race was white, black, or other. Black was coded $=1$ if the respondent self-identified s as black. "Other" was coded $=1$ if the respondent indicated that they were a member of a nonblack minority group.

Education was (1) high school, (2) some college, (3) baccalaureate degree, or (4) more than the baccalaureate.

Certification was coded as having at least one of the following professional certifications: Certified Fundraising Executive (CFRE), Advanced Certified Fundraising Executive (ACFRE), or Fellow for the Association of Healthcare Philanthropy (FAHP), or other.

Year was coded as year of the survey. Year 1 is the comparison measure. 


\section{Analysis and Results}

The Carroll, Hughes, and Luksetich (2005) study raises the question of the causality between pay and performance: Do employees work harder when they are paid more, or do harder-working employees get paid more? Given this issue of simultaneity and endogeneity, the estimation process is less clear-cut than might be desired. To account for this, we use a two-stage simultaneous estimation process (2SLS).

\section{Model Used for Analysis}

We first estimate compensation using pooled time-series crosssectional ordinary least squares (OLS) to find the impact of productivity and other variables on salary and bonus among different fundraising positions. We have an unbalanced panel with unmatched survey respondents each year. Therefore, in order to maximize the power of the regressions, we include all respondents in each year for each position and control for year-specific effects, which would capture differences in the overall macroeconomic effects in a given year.

In order to estimate the effects of performance on pay, we need to find a measure of performance or productivity that is exogenous or independent of compensation. To do this, we estimate productivity (money raised) based on the size of the development budget and the development staff, as well as the other independent variables we used to estimate compensation. We use the size of the development budget and the development staff as instrumental variables to estimate productivity (money raised), because these variables are arguably related to the amounts raised but unrelated directly to compensation. In the second stage, we use the independently estimated value of productivity (money raised) as an independent variable to estimate the pay-for-performance relationship and the effects of the other independent variables on compensation.

We first examine the relationship between pay and performance for fundraising professionals and refer to the pooled OLS regression results in Table 1. Looking first at the results for each position only (see Table 1), we find that a 10 percent increase in funds raised by the organization is significantly associated with a 0.9 percent raise in salary, as well as a significant increase in bonuses for the CDOs. In addition, deputy directors earned approximately a 0.6 percent increase in salary for a 10 percent increase in funds raised. Dollars raised is not significantly related to either of the compensation variables for staff or consultant, which might be a reflection of either the indirect effects of these positions or the less precise meaning of consultants.

In Table 2, we provide the estimates of our measure of productivity (money raised) using LnBudget and Staff (size) as instrumental variables that are independent of compensation but valid explanatory variables for productivity. We find that both LnBudget and Staff are highly significant variables in explaining productivity (money raised)

\begin{tabular}{c} 
Do employees \\
work harder \\
when they are \\
paid more, or do \\
harder-working \\
employees get \\
paid more? \\
\hline
\end{tabular}




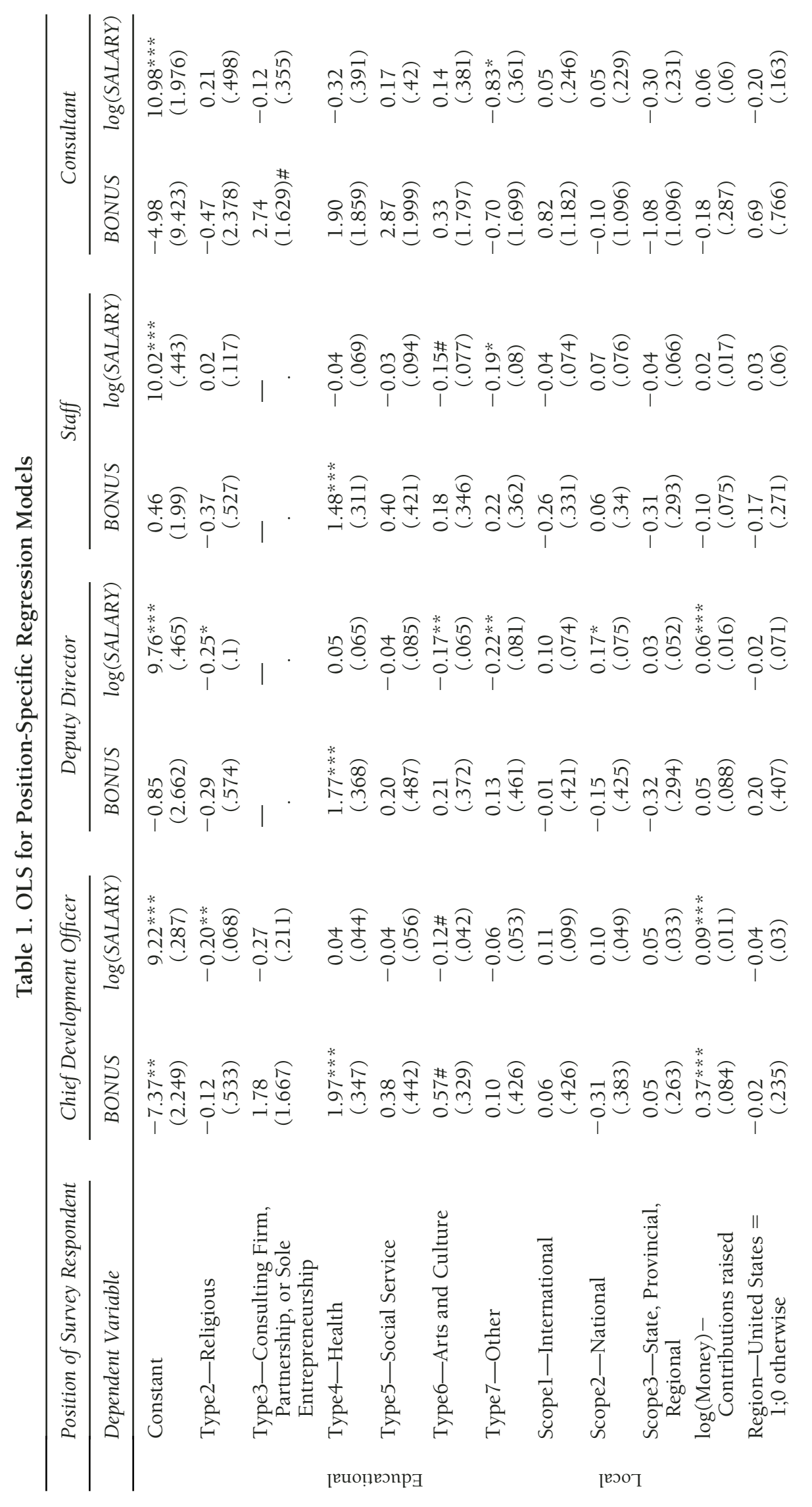




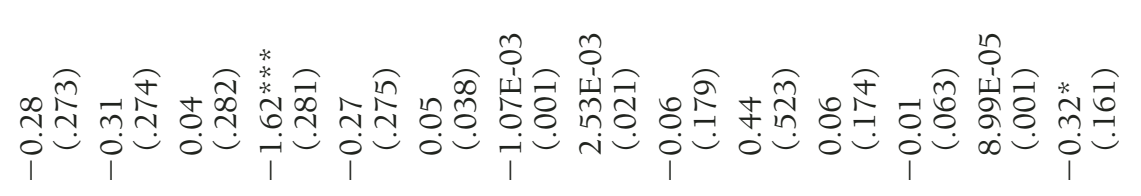

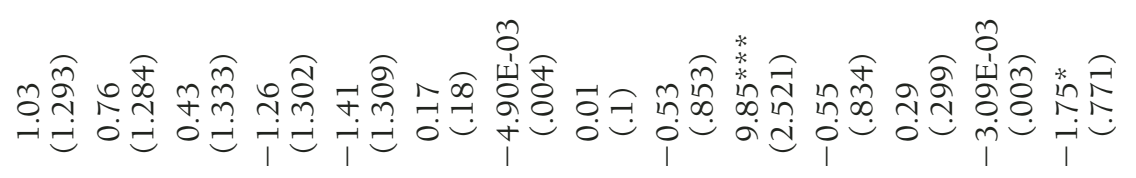

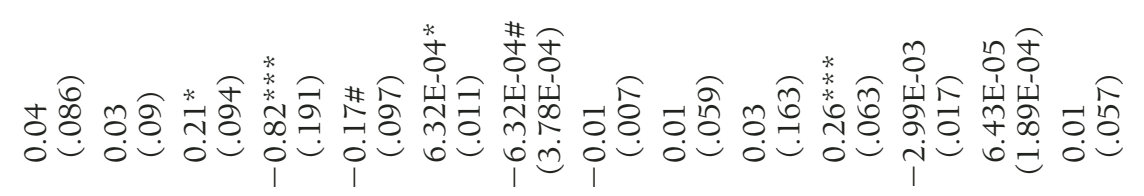

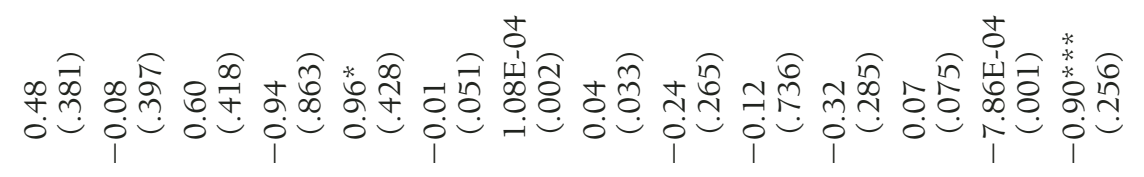

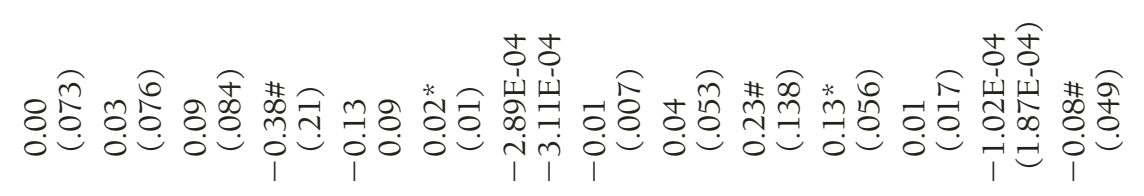

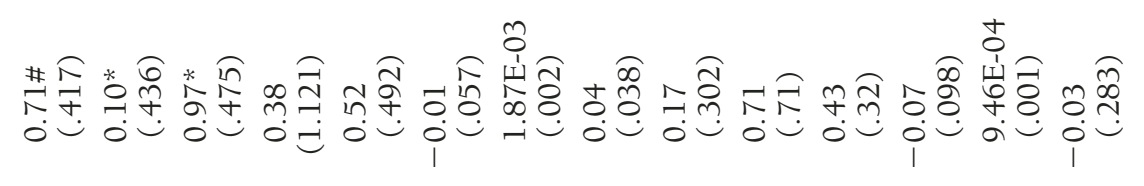

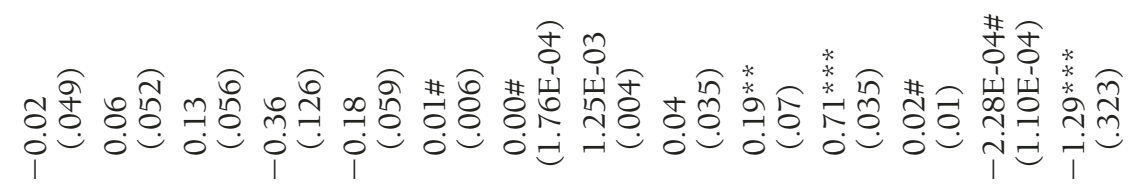

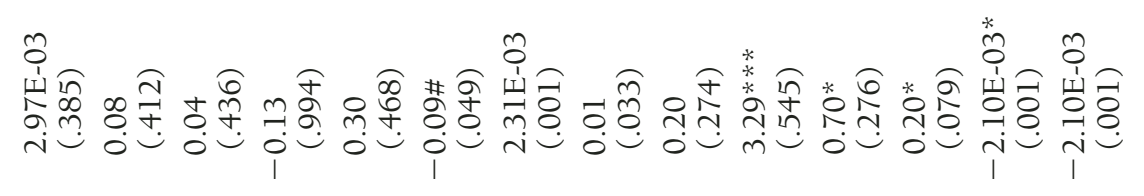

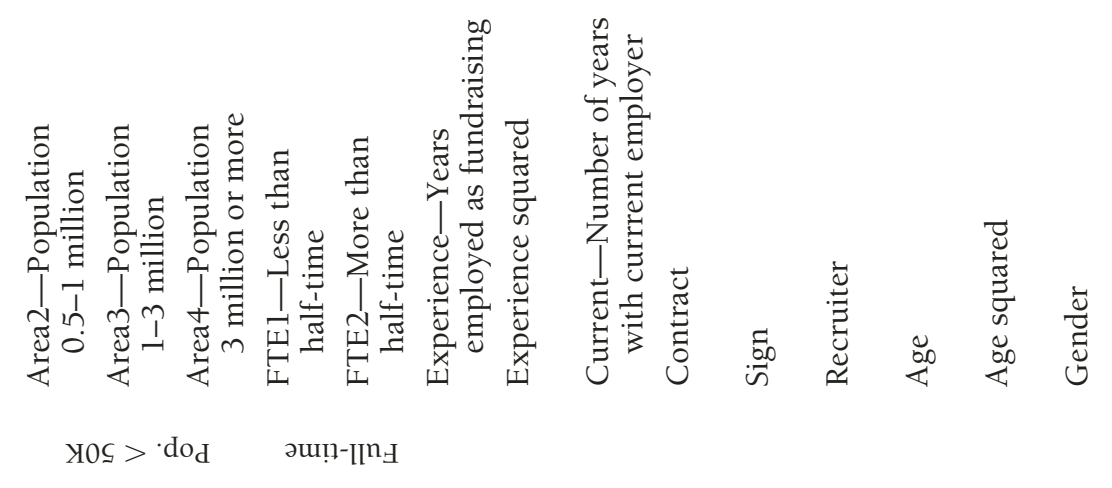




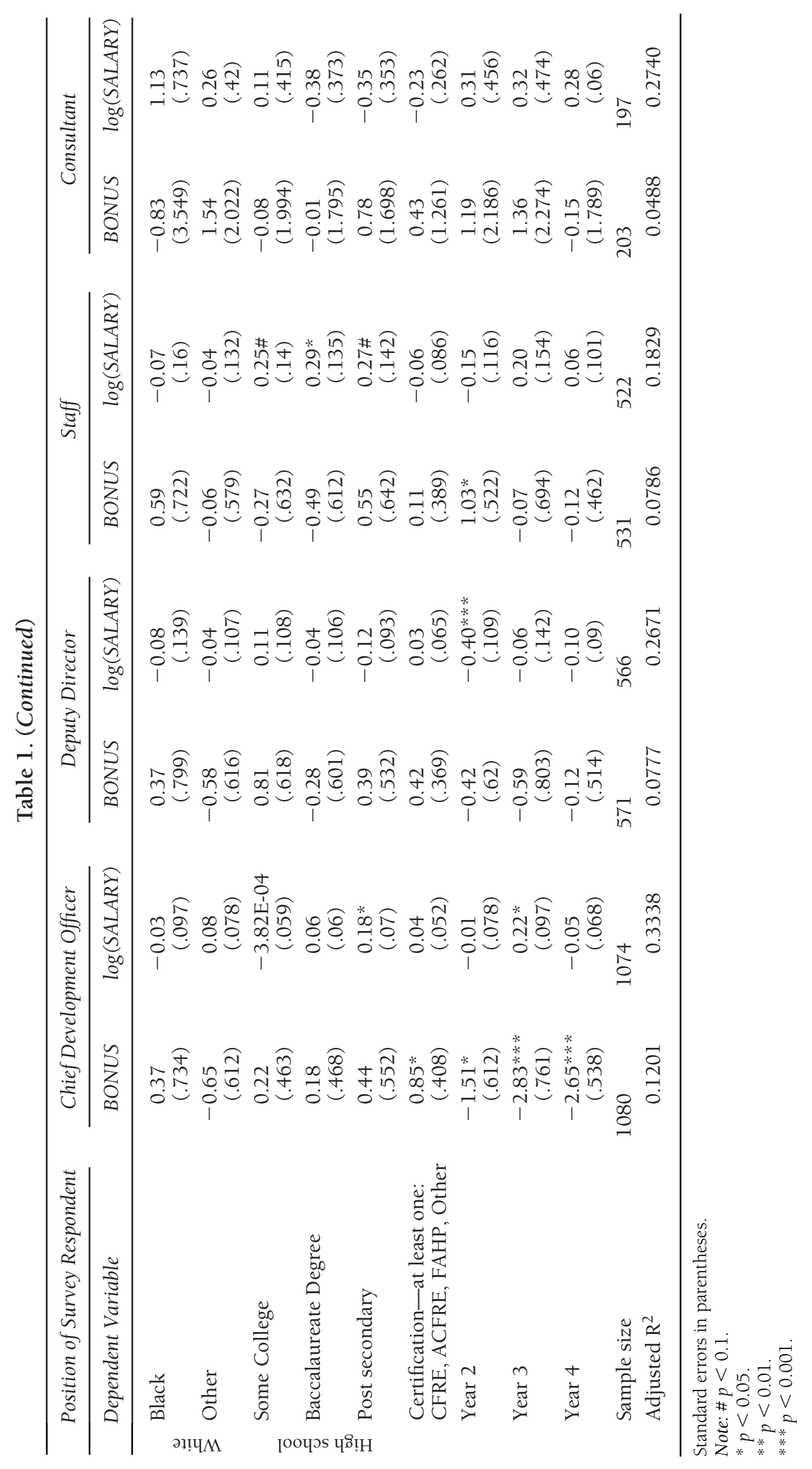




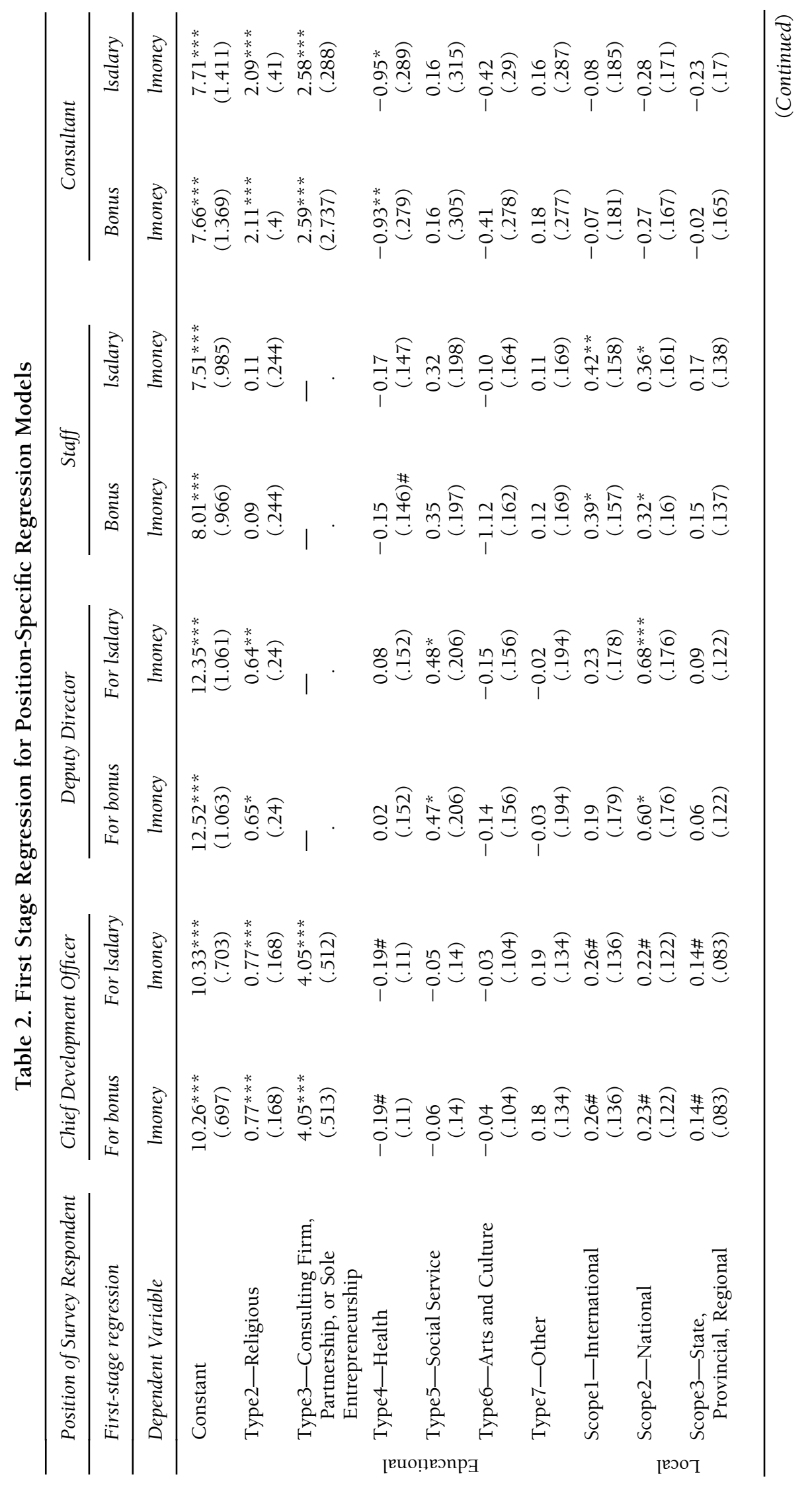




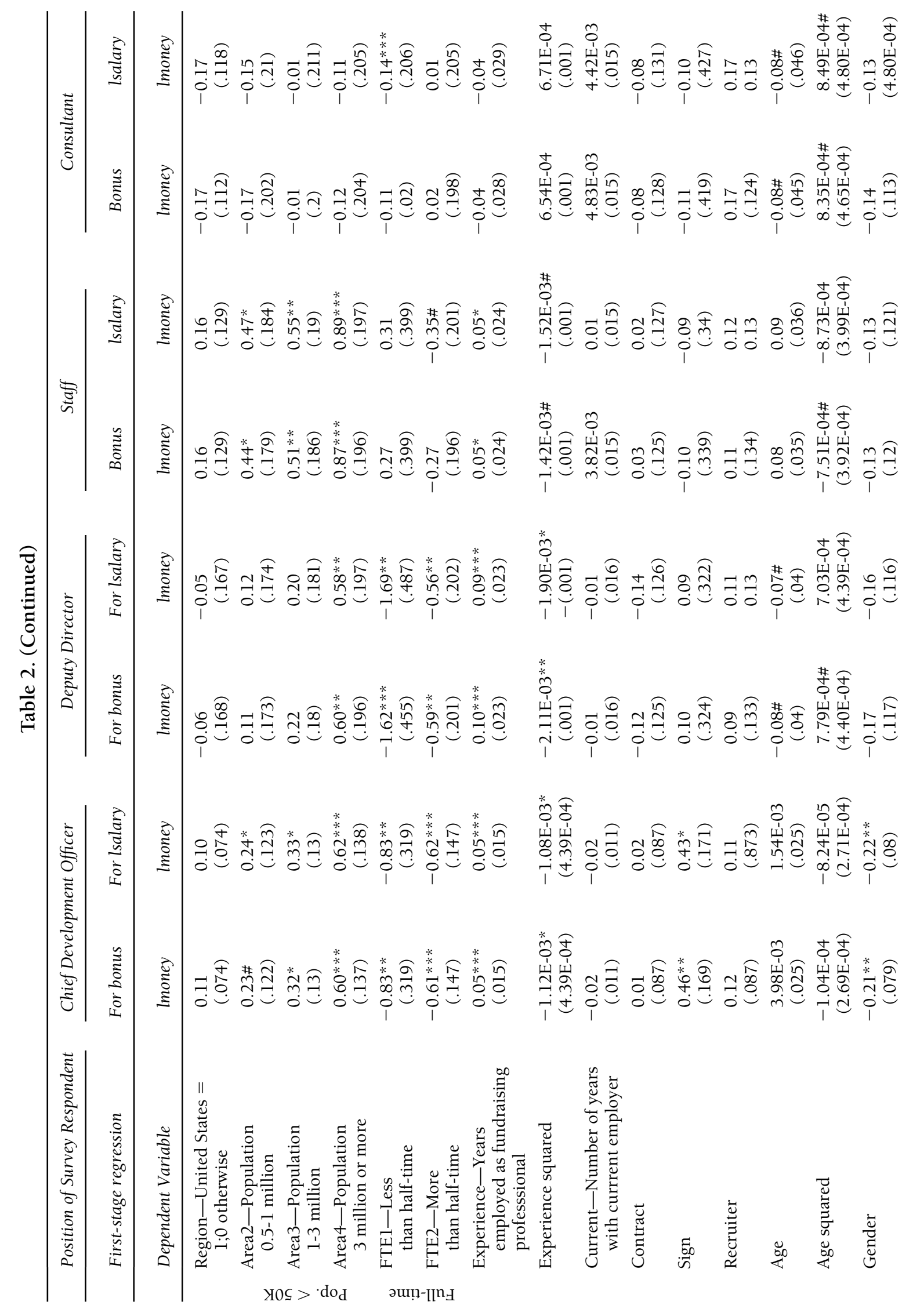




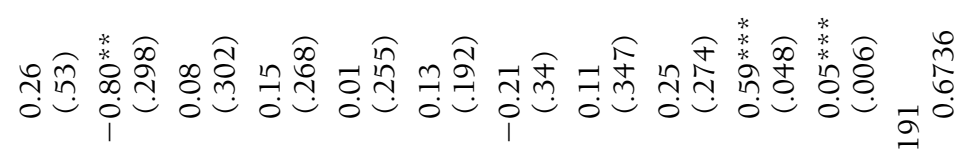

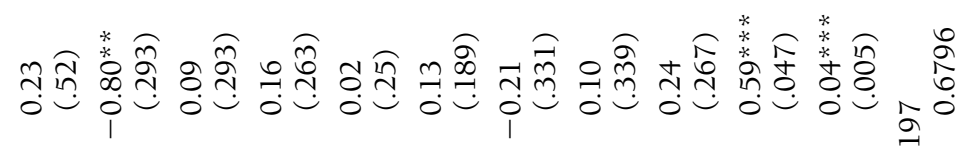

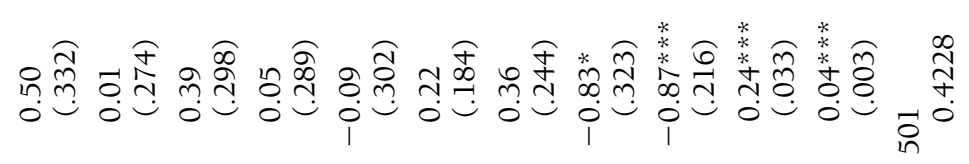

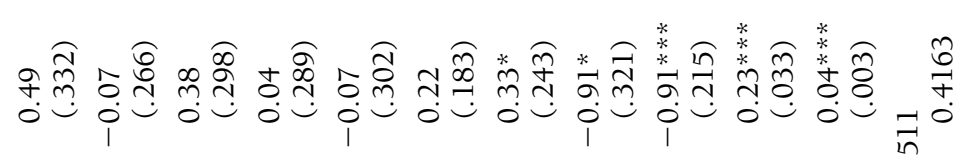

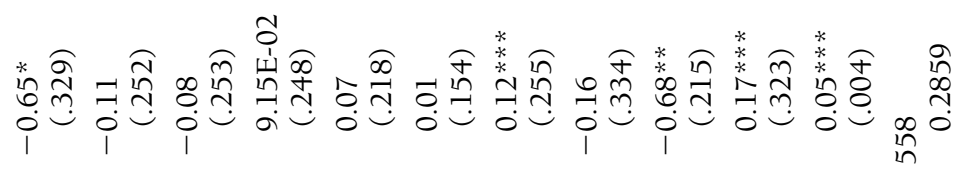

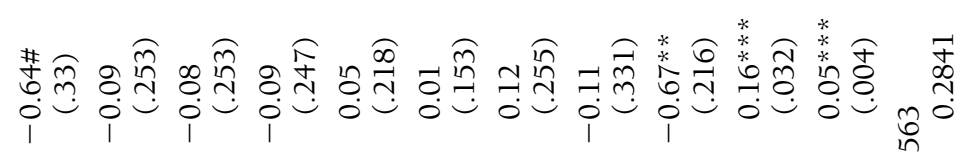

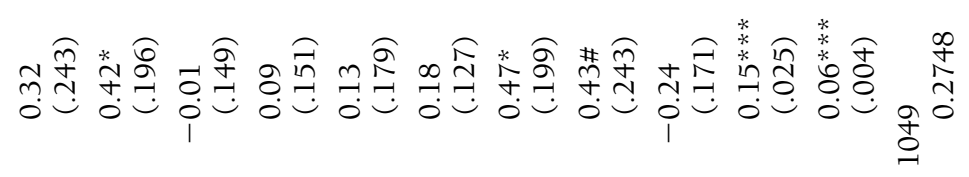

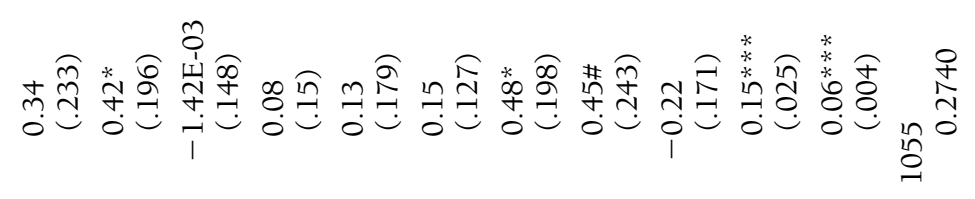

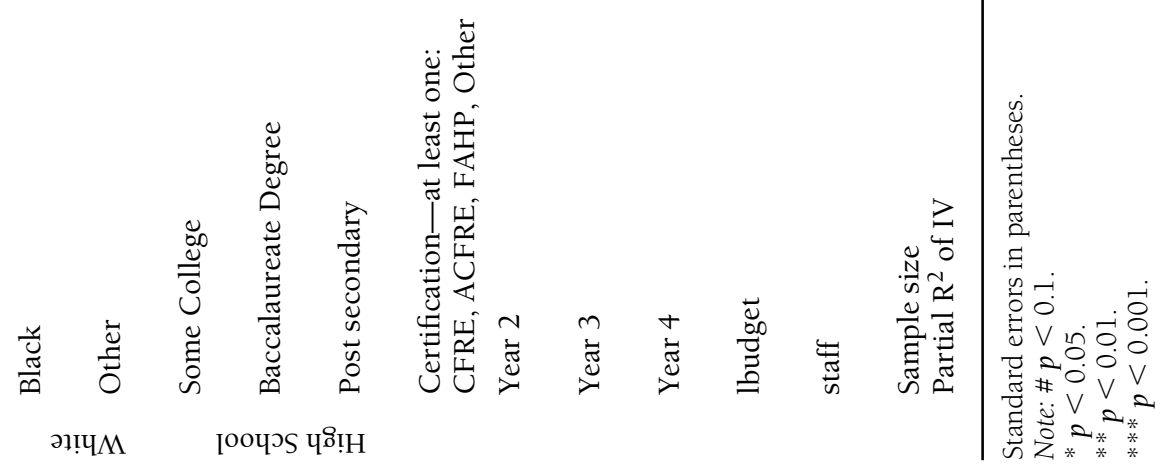




\begin{tabular}{c}
\hline Fundraising \\
productivity is \\
not associated \\
with a significant \\
increase in \\
bonuses-except \\
for chief \\
development \\
officers. \\
\hline
\end{tabular}

We find evidence
supportive of the
notion of pay for
performance
among
fundraisers.

across all types of fundraising positions. Given this and the theoretical distinction between their roles in explaining productivity directly but that they are arguably independent from explaining compensation directly, we determine that they are valid instrumental variables. Therefore, we include them in the second stage of our analysis.

Table 3 presents the results of our 2SLS simultaneous estimates. In this estimate, we find that productivity (LnMoney) has a positive and significant effect on the salary of each type of fundraising position. The strongest effect is for chief development officers, for whom a 10 percent increase in money raised is associated with a 1.4 percent increase in salary. Fundraising productivity (LMoney raised) is not associated with a significant increase in bonuses-except for CDOs. This may not be too surprising: if any position would have a variable compensation component, it would be the CDO, who is chiefly responsible for all aspects of fundraising at the organization. For the deputy directors, a 10 percent increase in productivity is associated with a 0.9 percent increase in salary. Staff experienced a similar change ( 0.8 percent); there was not a significant association between pay and performance for consultants.

Our results indicate a statistically significant relationship between pay and performance for most fundraising positions. Controlling for differences in mission, geographic scope, geographical population, size of the nonprofit, and so forth, as well as several human capital variables, we find evidence supportive of the notion of pay for performance among fundraisers.

\section{Are There Gender Differences in Compensation?}

We performed a series of $t$ tests for differences between the means for men $(n=767)$ and women $(n=1,672)$ fundraisers. Noteworthy results presented in Table 4 indicate that men have significantly higher average salaries and larger shares of income from bonuses. (Men's bonuses are, on average, over 70 percent higher than those of women.) Men are more likely than women to serve in educational, religious, and consulting organizations, whereas women are more likely to serve in social services and arts and cultural nonprofits. Geographically men are more likely to work in international and national nonprofits, and women are more likely to work in local nonprofits. Men raised significantly more money and worked for organizations with larger development staffs and budgets. Men also had significantly more overall experience as fundraisers (four more years) but had similar tenures with the current employer. Men were slightly older (3.6 years) and were almost twice as likely as females to have been hired through a recruiter. Men were more likely to have significantly more education than women. Hence, if it were not possible to refine our analysis further, we might conclude that men are paid more than women, but they perhaps had earned higher compensation because, on average, they raise more money, work in larger, more complex organizations, and have more education than women. 


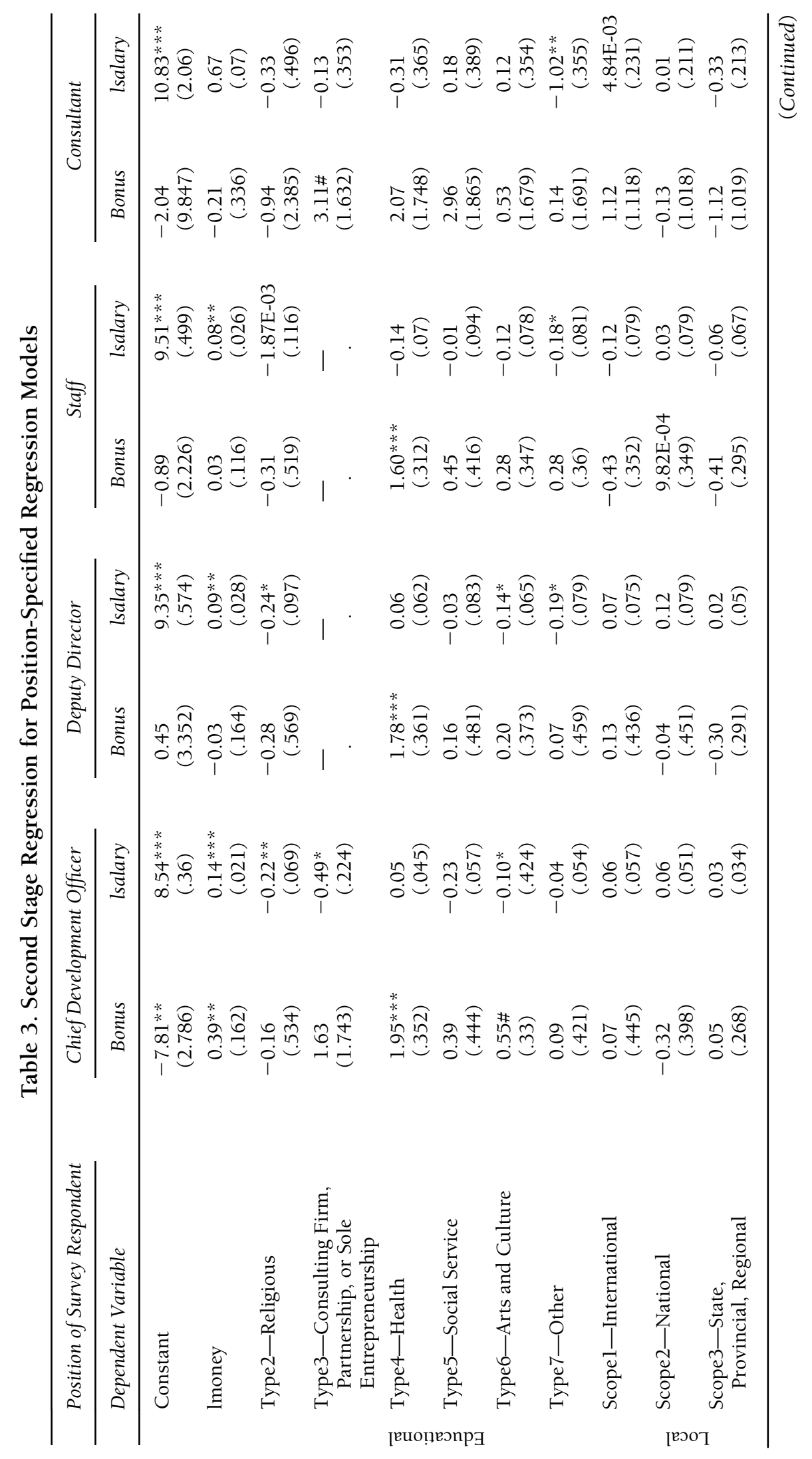




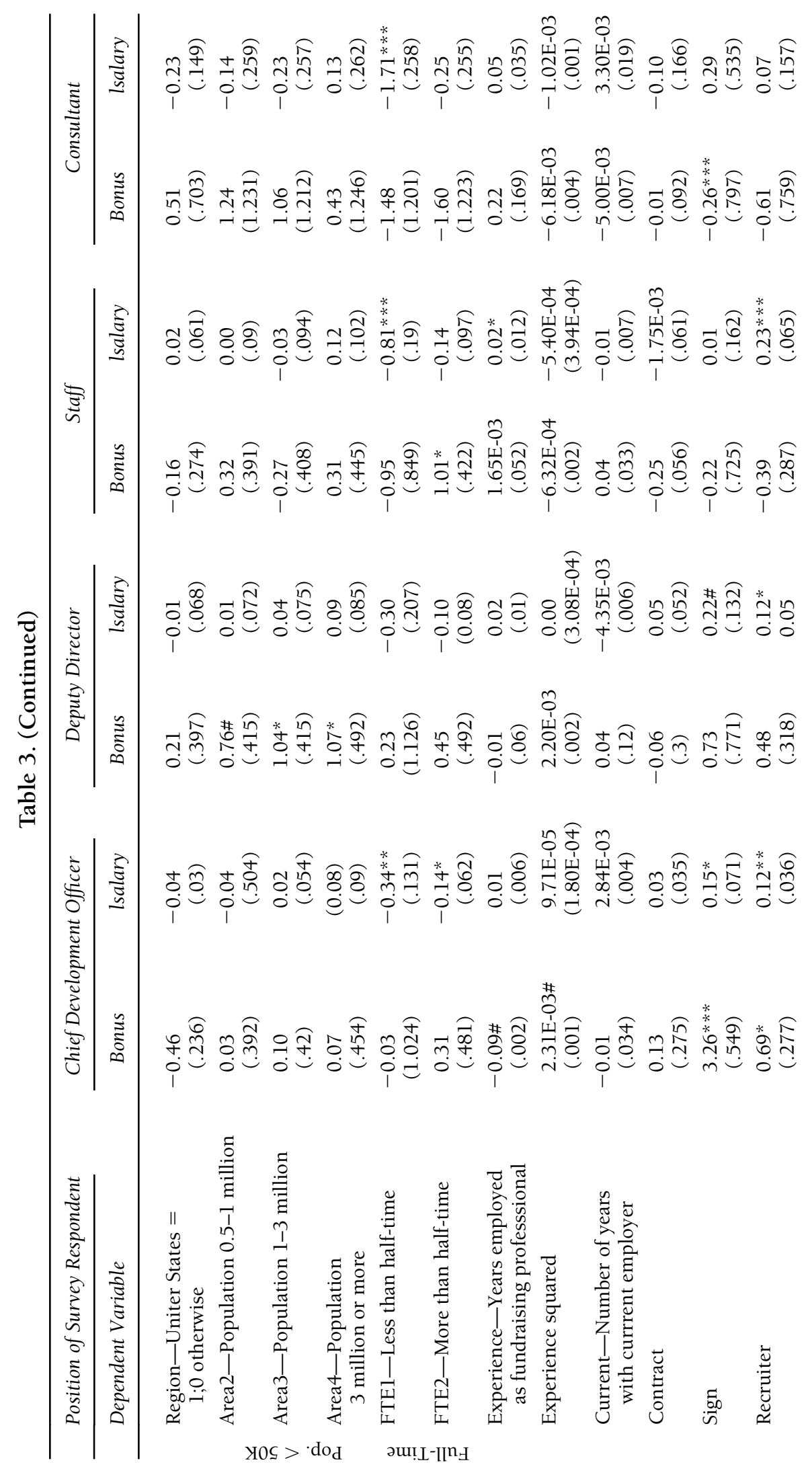


i

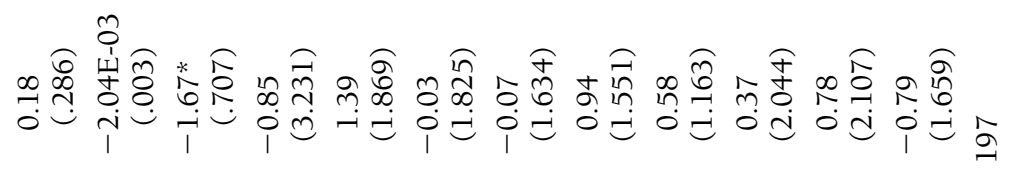
i

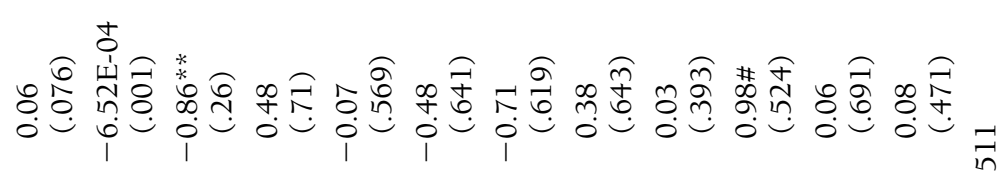
o: i 苦委

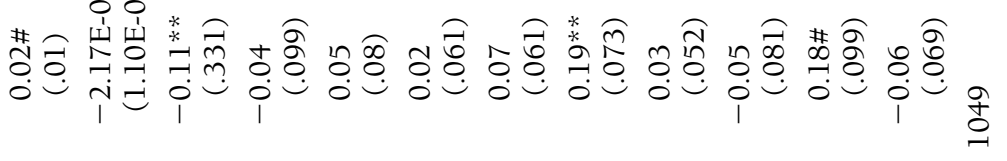

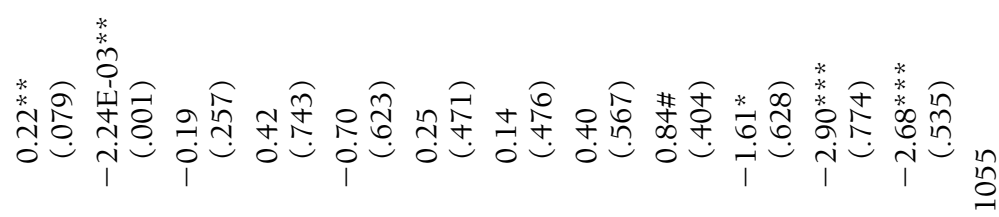

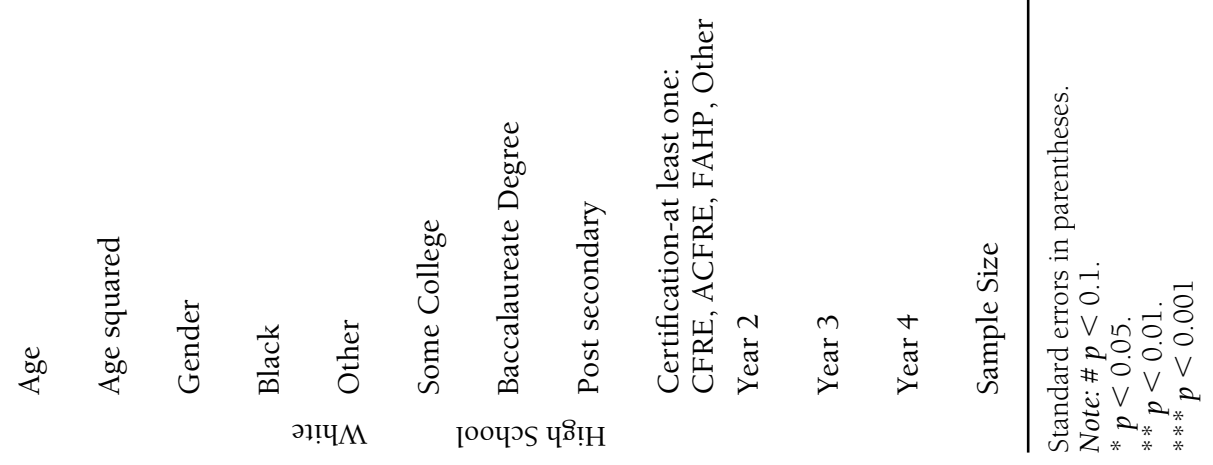


Table 4. Test for Equality of Means for Entire Sample

\begin{tabular}{|c|c|c|c|c|c|}
\hline & \multicolumn{5}{|c|}{ Gender Difference } \\
\hline & $\begin{array}{c}\text { Males } \\
N=767\end{array}$ & $\begin{array}{l}\text { Females } \\
N=1672\end{array}$ & Difference & t-stat & Significance \\
\hline Bonus & $\begin{array}{c}1.711 \\
(4.358)\end{array}$ & $\begin{array}{c}0.997 \\
(3.077)\end{array}$ & 0.714 & 4.091 & $* * *$ \\
\hline $\log$ (Salary) & $\begin{array}{l}11.190 \\
(0.772)\end{array}$ & $\begin{array}{l}10.927 \\
(0.638)\end{array}$ & 0.263 & 8.218 & $* * *$ \\
\hline Type1-Educational & $\begin{array}{l}0.302 \\
(0.46)\end{array}$ & $\begin{array}{c}0.249 \\
(0.433)\end{array}$ & 0.053 & 2.696 & $* *$ \\
\hline Type2-Religious & $\begin{array}{c}0.085 \\
(0.279)\end{array}$ & $\begin{array}{c}0.038 \\
(0.192)\end{array}$ & 0.046 & 4.185 & $* * *$ \\
\hline $\begin{array}{l}\text { Type3-Consulting } \\
\text { Firm, Partnership, or } \\
\text { Sole Entrepreneurship }\end{array}$ & $\begin{array}{c}0.076 \\
(0.265)\end{array}$ & $\begin{array}{c}0.045 \\
(0.207)\end{array}$ & 0.031 & 2.845 & $* *$ \\
\hline Type4-Health & $\begin{array}{c}0.213 \\
(0.409)\end{array}$ & $\begin{array}{c}0.199 \\
(0.399)\end{array}$ & 0.013 & 0.754 & \\
\hline Type5-Social Service & $\begin{array}{c}0.057 \\
(0.233)\end{array}$ & $\begin{array}{c}0.099 \\
(0.299)\end{array}$ & -0.042 & -3.762 & $* * *$ \\
\hline $\begin{array}{l}\text { Type6-Arts } \\
\text { and Culture }\end{array}$ & $\begin{array}{c}0.171 \\
(0.377)\end{array}$ & $\begin{array}{l}0.257 \\
(0.437)\end{array}$ & -0.086 & -4.994 & $* * *$ \\
\hline Type7-Other & $\begin{array}{c}0.096 \\
(0.295)\end{array}$ & $\begin{array}{c}0.112 \\
(0.315)\end{array}$ & -0.015 & -1.167 & \\
\hline $\begin{array}{l}\text { Scopel- } \\
\text { International }\end{array}$ & $\begin{array}{l}0.180 \\
(0.384)\end{array}$ & $\begin{array}{c}0.126 \\
(0.332)\end{array}$ & 0.054 & 3.341 & $* * *$ \\
\hline Scope2-National & $\begin{array}{c}0.197 \\
(0.398)\end{array}$ & $\begin{array}{c}0.137 \\
(0.344)\end{array}$ & 0.060 & 3.599 & $* * *$ \\
\hline $\begin{array}{l}\text { Scope3-State, } \\
\text { Provincial, Regional }\end{array}$ & $\begin{array}{c}0.308 \\
(0.462)\end{array}$ & $\begin{array}{c}0.309 \\
(0.462)\end{array}$ & -0.002 & -0.075 & \\
\hline Scope4-Local & $\begin{array}{c}0.310 \\
(0.463)\end{array}$ & $\begin{array}{l}0.425 \\
(0.495)\end{array}$ & -0.115 & -5.571 & $* * *$ \\
\hline $\begin{array}{l}\log (\text { Money })- \\
\quad \text { Contributions raised }\end{array}$ & $\begin{array}{l}15.046 \\
(2.033)\end{array}$ & $\begin{array}{l}14.368 \\
(1.920)\end{array}$ & 0.679 & 7.788 & $* * *$ \\
\hline $\log ($ Budget $)$ & $\begin{array}{l}15.642 \\
(2.036)\end{array}$ & $\begin{array}{l}15.268 \\
(1.854)\end{array}$ & 0.374 & 4.326 & $* * *$ \\
\hline Staff & $\begin{array}{l}12.928 \\
(16.747)\end{array}$ & $\begin{array}{c}9.186 \\
(13.930)\end{array}$ & 3.742 & 5.392 & $* * *$ \\
\hline $\begin{array}{l}\text { Region-U.S }= \\
\quad 1 ; 0 \text { otherwise }\end{array}$ & $\begin{array}{c}0.687 \\
(0.464)\end{array}$ & $\begin{array}{c}0.670 \\
(0.470)\end{array}$ & 0.017 & 0.819 & \\
\hline $\begin{array}{l}\text { Areal-Population } \\
0-0.5 \text { million }\end{array}$ & $\begin{array}{c}0.095 \\
(0.294)\end{array}$ & $\begin{array}{c}0.097 \\
(0.296)\end{array}$ & -0.002 & -0.134 & \\
\hline $\begin{array}{l}\text { Area2-Population } \\
0.5-1 \text { million }\end{array}$ & $\begin{array}{c}0.374 \\
(0.484)\end{array}$ & $\begin{array}{c}0.395 \\
(0.489)\end{array}$ & -0.021 & -0.998 & \\
\hline $\begin{array}{l}\text { Area3-Population } \\
\text { 1-3 million }\end{array}$ & $\begin{array}{c}0.272 \\
(0.446)\end{array}$ & $\begin{array}{c}0.281 \\
(0.450)\end{array}$ & -0.009 & -0.442 & \\
\hline $\begin{array}{l}\text { Area4-Population } \\
3 \text { million or more }\end{array}$ & $\begin{array}{c}0.258 \\
(0.438)\end{array}$ & $\begin{array}{c}0.219 \\
(0.414)\end{array}$ & 0.039 & 2.059 & * \\
\hline $\begin{array}{l}\text { FTEl-Less than } \\
\text { half-time }\end{array}$ & $\begin{array}{c}0.021 \\
(0.143)\end{array}$ & $\begin{array}{c}0.026 \\
(0.158)\end{array}$ & -0.005 & -0.753 & \\
\hline $\begin{array}{l}\text { FTE2-More } \\
\text { than half-time }\end{array}$ & $\begin{array}{c}0.239 \\
(0.427)\end{array}$ & $\begin{array}{l}0.266 \\
(0.442)\end{array}$ & -0.027 & -1.433 & \\
\hline FTE3-Full-time & $\begin{array}{c}0.700 \\
(0.458)\end{array}$ & $\begin{array}{c}0.677 \\
(0.468)\end{array}$ & 0.023 & 1.148 & \\
\hline
\end{tabular}

(Continued) 
Table 4. (Continued)

\begin{tabular}{|c|c|c|c|c|c|}
\hline & \multicolumn{5}{|c|}{ Gender Difference } \\
\hline & $\begin{array}{c}\text { Males } \\
N=767\end{array}$ & $\begin{array}{c}\text { Females } \\
N=1672\end{array}$ & Difference & t-stat & Significance \\
\hline $\begin{array}{l}\text { Experience-Years } \\
\text { employed as fundrais- } \\
\text { ing professional }\end{array}$ & $\begin{array}{l}16.056 \\
(9.464)\end{array}$ & $\begin{array}{l}12.332 \\
(7.731)\end{array}$ & 3.724 & 9.535 & $* * *$ \\
\hline $\begin{array}{l}\text { Current-Number of } \\
\text { Years with current } \\
\text { employer }\end{array}$ & $\begin{array}{c}4.501 \\
(3.414)\end{array}$ & $\begin{array}{c}4.421 \\
(3.364)\end{array}$ & 0.080 & 0.537 & \\
\hline Contract & $\begin{array}{c}0.240 \\
(0.427)\end{array}$ & $\begin{array}{c}0.236 \\
(0.425)\end{array}$ & 0.004 & 0.196 & \\
\hline Sign & $\begin{array}{c}0.030 \\
(0.171)\end{array}$ & $\begin{array}{c}0.034 \\
(0.182)\end{array}$ & -0.004 & -0.540 & \\
\hline Recruiter & $\begin{array}{c}0.369 \\
(0.483)\end{array}$ & $\begin{array}{c}0.197 \\
(0.398)\end{array}$ & 0.172 & 8.626 & $* * *$ \\
\hline Age & $\begin{array}{c}46.497 \\
(11.697)\end{array}$ & $\begin{array}{c}42.900 \\
(11.798)\end{array}$ & 3.597 & 7.033 & $* * *$ \\
\hline High School & $\begin{array}{c}0.025 \\
(0.156)\end{array}$ & $\begin{array}{c}0.056 \\
(0.229)\end{array}$ & -0.031 & -3.888 & $* * *$ \\
\hline Some College & $\begin{array}{c}0.167 \\
(0.373)\end{array}$ & $\begin{array}{c}0.228 \\
(0.420)\end{array}$ & -0.061 & -3.601 & $* * *$ \\
\hline $\begin{array}{c}\text { Baccalaureate } \\
\text { Degree }\end{array}$ & $\begin{array}{c}0.249 \\
(0.433)\end{array}$ & $\begin{array}{c}0.232 \\
(0.422)\end{array}$ & 0.017 & 0.906 & \\
\hline Post Secondary & $\begin{array}{c}0.525 \\
(0.500)\end{array}$ & $\begin{array}{c}0.476 \\
(0.500)\end{array}$ & 0.049 & 2.265 & * \\
\hline $\begin{array}{l}\text { Certification-at } \\
\text { least one: } \\
\text { CFRE, ACFRE, } \\
\text { FAHP, Other }\end{array}$ & $\begin{array}{c}0.600 \\
(0.490)\end{array}$ & $\begin{array}{c}0.570 \\
(0.495)\end{array}$ & 0.030 & 1.388 & \\
\hline Yearl & $\begin{array}{c}0.270 \\
(0.444)\end{array}$ & $\begin{array}{c}0.261 \\
(0.439)\end{array}$ & 0.009 & 0.472 & \\
\hline Year2 & $\begin{array}{c}0.231 \\
(0.422)\end{array}$ & $\begin{array}{c}0.268 \\
(0.443)\end{array}$ & -0.037 & -1.989 & * \\
\hline Year3 & $\begin{array}{c}0.252 \\
(0.434)\end{array}$ & $\begin{array}{c}0.234 \\
(0.424)\end{array}$ & 0.017 & 0.914 & \\
\hline Year4 & $\begin{array}{c}0.248 \\
(0.432)\end{array}$ & $\begin{array}{c}0.237 \\
(0.425)\end{array}$ & 0.011 & 0.580 & \\
\hline
\end{tabular}

By using regression models, we can examine these issues more rigorously. Table 3 shows that female CDOs are paid approximately 11 percent lower salaries ${ }^{1}$ than male CDOs $(p<.01)$ —even after controlling for a wide range of organizational and individual variables, including dollars raised by the organization. Gender differences in bonuses for CDOs were not significant. Similarly, female deputy directors are paid approximately 8 percent less than males (but this difference only approaches significance, $p<.1$ ), and like the CDOs, there were no significant gender differences in bonuses among the deputy directors. Female staffers were not paid less in salary than men but received significantly lower bonuses. Female consultants 


\begin{tabular}{c}
\hline We find a \\
substantial \\
earnings penalty \\
for those working \\
less than half- \\
time. \\
\hline
\end{tabular}

received approximately 36 percent lower salaries than male consultants and were given significantly lower bonuses as well.

\section{Other Determinants of Bonus and Salary}

The following is a description of other factors that affect bonus and salary for fundraising professionals. To simplify our presentation, we discus only those in our final estimation of the 2SLS process in Table 3 and the results that are statistically significant.

Mission of the Nonprofit. We used education as the reference group for this set of variables. We found that CDOs in religious nonprofits earn approximately 22 percent lower salaries compared to education, and deputy directors earn approximately 24 percent less. Health care fundraisers earn approximately the same salaries as their peers in education, but health care fundraisers earn significantly higher bonuses than their counterparts in education. CDOs in arts and culture nonprofits earn approximately 10 percent less and deputy directors earn approximately 14 percent less than their educational counterparts. Deputy directors, staff, and consultants in other subsectors earn substantially less than those in education. CDOs in consulting firms earn less than their educational peers, but there are not enough consultants in the deputy directors and staff categories to isolate an independent effect. Perhaps most surprising is that fundraisers in social services do not earn significantly different salaries or bonuses than their counterparts in education.

Population of Base City. After controlling for all other factors, we found no significant differences in the base salaries of fundraisers in any city size. However, deputy directors in various city sizes were paid significantly higher bonuses than those living in the smallest towns (population less than fifty thousand).

Full-Time Status. We find a substantial earnings penalty for those working less than half-time. For example, CDOs who work less than half-time earn approximately 34 percent less than full-time CDOs. While it is somewhat surprising that the pay penalty for those working less than half-time is less than 50 percent, it may be that CDOs who are permitted to work less than half-time are highly productive or very successful, or both. It may be necessary to pay them a premium relative to the estimated share of salary in order to retain them. The penalties are even larger for staff and consultants. CDOs who work more than half-time (but less than full time) are paid approximately 14 percent less than full-timers. Staff who work more than half-time are paid substantially higher bonuses.

Hiring Practices. The existence of an employment contract had no effect for fundraisers' compensation after holding constant other variables. Payment of a signing bonus has positive and significant effect for the base salary of CDOs and approached significance for deputy directors. Signing bonuses also had a positive and large effect on the bonuses of CDOs and a small but negative effect on the bonuses of consultants. Those CDOs, deputy directors, and staffers 
who were hired through a recruiter experienced a significant bump up in salaries (12 to 23 percent), and CDOs also experienced a significant increase in their bonus if they were hired through a recruiter.

\section{Human Capital Effects}

We control for and describe here several human capital effects: age, race, education, certification, and fundraising experience.

Age. Age captures general human capital for experience, which is not captured in other human capital variables, and tends to have a positive and significant effect on both salary and bonuses for all positions. Age squared is negative and significant, which suggests a curvilinear effect (diminishing returns).

Race. Race is generally not significant (either black or other) for any of the positions.

Education. While having some college or even a B.A. or B.S. did not enhance one's salary relative to high school graduates (or less), having postsecondary training has a positive effect on the base salary of CDOs.

Certification. Having one or more fundraising-related certification does not have much of an effect on compensation.

Fundraising experience. Surprisingly, fundraising experience has only a marginally significant and small effect on the bonuses of CDOs, and that effect is negative while experience squared is positive. Staff experience is small but positive and significant with respect to base salary. Tenure with current employer is also somewhat surprisingly unimportant for both salary and bonus and does not attain statistical significance.

\section{Discussion and Conclusion}

The focus of our study was to ascertain the critical factors that determine compensation for individuals who are employed as fundraising professionals in nonprofit organizations. In general, our results indicate that when we control for organizational characteristics and human capital variables, performance does play a positive and significant role in determining both salary and bonus, particularly for individuals employed as CDOs. We used instrumental variables and simultaneous 2SLS to control for the endogeneity between pay and performance. Our instrumental variables provided good estimates of productivity, which enabled us to estimate the exogenous effects of productivity on compensation, holding constant all other variables. Thus, we can be more confident in our results that suggest performance has a strong and significant effect on compensation.

Contrary to the conclusions drawn from previous reviews of the pay-performance relationship in the for-profit sector (for example, Barkema and Gomez-Mejia, 1998; Tosi, Werner, Katz, and 


Our study found
a significant and
positive
relationship
between money
raised and
compensation.

Gomez-Mejia, 2000), indicating a weak pay-performance correlation, our study found a significant and positive relationship between money raised and compensation. This finding is especially compelling in that the ethical standards for fundraising professionals preclude these individuals from being paid on a commission basis. Although we were not able to ascertain whether the fundraising professionals in our sample were operating under explicit performancebased compensation systems, our results indicate that there appears to be a pay-performance linkage, suggesting at least implied contracts rewarding performance based on money raised.

Our finding of a significant pay-performance linkage for fundraisers employed in nonprofits is somewhat unusual. The theoretical literature suggests that managers and other stakeholders would be reluctant to tie pay to performance for the following reasons: (1) it is difficult to measure results in nonprofits, (2) managers self-select to work in nonprofits and may be more risk averse in terms of compensation, and (3) the trust of donors may be in jeopardy if compensation is perceived as being too high. Empirical research conducted on executive pay in nonprofits provides general support for these theoretical explanations-where managerial pay is more strongly related to organizational size than managerial performance (for example, Hallock, 2002a; Oster, 1998; Pink and Leatt, 1991).

There may be several explanations for our findings. First, for fundraisers, where a financial measure of performance relates directly to job responsibilities, pay and performance are more likely to be related-unlike most managerial positions in nonprofits, where pay and performance have not found much support in the empirical literature. Second, individuals who self-select into fundraising roles may behave more like those in the private sector-less risk averse in terms of linking their pay to performance. Fundraisers may be acting more like workers in the for-profit sector due to the nature of their job responsibilities and not sorting in the ways that typically have been found in nonprofits. These findings suggest the importance of examining the roles that individuals play in the nonprofit sector in terms of self-selection.

Our results also indicate a gender-pay gap, even after controlling for all factors traditionally associated with pay differentials between males and females. Women fundraising professionals who are CDOs earn significantly lower salaries then men, female staff earn significantly lower bonuses, and consultants earn significantly lower bonus and salary.

Our research is consistent with the most recent survey conducted on nonprofit pay that found (1) compensation differences across types of nonprofits (fundraising professionals employed in the education and health areas tend to pay their executives more than other types of nonprofits), (2) geographical location does not appear to affect compensation, and (3) size of the nonprofit does not affect compensation as much as the gender of employees (GuideStar,

Nonprofit Management $\mathcal{E}$ Leadership

DOI: $10.1002 / \mathrm{nml}$ 
2005). Interestingly, the human capital variables one would expect to be significantly related to compensation did not have much of an effect. Fundraising experience was only marginally related to compensation, and tenure with employer had no effect. Race and education appear to have little impact as well.

Although the issue of incentive pay for fundraisers is controversial, compensation based on money raised is a relevant and timely subject for those in the fundraising field. Incentive pay plans are still relatively rare, but they are becoming more common, especially at large nonprofits (Gose, 2002). According to results of an online ethics and compensation survey sent to members of the AFP, 57 percent had reported that they had been asked to consider raising charitable funds on a commission basis-even though this practice is prohibited under the AFP Code of Ethical Principles and Standards of Professional Practice (Sczudlo, 2003). Furthermore, reports in the philanthropic and nonprofit field give account of organizations that use incentive pay to retain top fundraisers on the job (for example, Gose, 2002). Our study suggests that the pay-performance relationship is present, even though it may not be made explicit in compensation policy. Future research should attempt to quantify whether the lack of a performance-based system depresses fundraising and focus on issues of efficiency rather than solely on the ethical concernsparticularly as pay-for-performance systems are beginning to be adopted in more nonprofits.

Finally, it is important to understand that "fundraising does not take place in a vacuum; it is one of the central elements of a larger system of philanthropy" and is misunderstood if reduced to simply the act of raising money (Payton, Russo, and Tempel, 1991, p. 4). Fundraisers rely on the mission of the nonprofit in justifying their fundraising role and hold themselves accountable to the public through ethical fundraising practices tied to the mission of the organization. As such, "fundraising is a moral action ... that engages fund raisers in the lives of other people for their benefit or for some larger public benefit as well as for the benefit of the fund raisers themselves" (Payton, Russo, and Tempel, 1991, p. 9). Future research examining the pay-performance relationship for fundraisers needs to keep in mind the context in which this occurs.

\section{Notes}

1. For variables that are logged, we use the elasticities directly from the tables to facilitate interpretation by the readers. In a log-log or log-level regression model, the estimates of the regression coefficients can provide an approximation of the percentage change of the dependent variable. This approximation is quite accurate if the regression coefficient is small, but if the coefficient is large, the approximation can become increasingly inaccurate. This approximation in our results varies from the true estimate by less than one percentage point in nearly all cases (except a couple of cases with very large percentage changes) and would not involve a change in either sign or level or significance. 
DEBRA J. MESCH is an associate professor of public and nonprofit management and philanthropic studies in the School of Public and Environmental Affairs at Indiana University-Purdue University, Indianapolis.

PATRICK M. ROONEY is professor of economics and philanthropic studies at Indiana University-Purdue University, Indianapolis, and director of research at the Center on Philanthropy at Indiana University.

\section{References}

Alvardo, E. I. "The Validity of Supplementary Pay Systems in Nonprofit Organizations." Nonprofit Management and Leadership, 1996, 6, 291-304.

Bailey, S. B., and Risher, H. "Not-for-Profits Try Out New Compensation Plans." Compensation and Benefits Review, 1996, 47-57.

Ballou, J. P., and Weisbrod, B. A. "Managerial Rewards and the Behavior of For-Profit, Governmental, and Nonprofit Organizations: Evidence from the Hospital Industry." Journal of Public Economics, 2003, 87, 1895-1920.

Barkema, H. G., and Gomez-Mejiz, L. R. "Managerial Compensation and Firm Performance: A General Research Framework." Academy of Management Journal, 1998, 47, 135-145.

Bertrand, M., and Hallock, K. F. "The Gender Gap in Top Corporate Jobs." Industrial and Labor Relations Review, 2001, 55, 3-21.

Blau, F. D. "Trends in the Well-Being of American Women, 1970-1995." Journal of Economic Literature, 1998, 36, 112-165.

Blau, F., and Ferber, M. The Economics of Women, Men and Work. (2nd ed.) Upper Saddle River, N.J.: Prentice Hall, 1992.

Blau, F., Ferber, M., and Winkler. The Economics of Women, Men and Work. (3rd ed.) Upper Saddle River, N.J.: Prentice Hall, 1998.

Brickley, J. S., and Van Horn, R. L. "Managerial Incentives in Nonprofit Organizations: Evidence from Hospitals." Journal of Law and Economics, 2002, 45, 227-249.

Carroll, T., Hughes, P., and Luksetich, W. "Managers of Nonprofit Organizations Are Rewarded for Performance." Nonprofit Management and Leadership, 2005, 16, 19-41.

Chauvin, K. W., and Ash, R. A. "Gender Earnings Differentials in Total Pay, Base Pay, and Contingent Pay." Industrial and Labor Relations Review, 1994, 47, 634-649.

Conry, J. C. "The Feminization of Fund Raising." In D. F. Burlingame and L. J. Hulse (eds.), Taking Fund Raising Seriously. San Francisco: Jossey-Bass, 1991.

Conry, J. C. "Gender and Pay Equity in the Fundraising Workforce: Implications for Practice and Policy." New Directions for Philanthropic Fundraising, 1998, 19, 73-91.

Deckop, J. R., and Cirka, C. C. "The Risk and Reward of a DoubleEdged Sword: Effects of a Merit Pay Program on Intrinsic Motivation." Nonprofit and Voluntary Sector Quarterly, 2000, 29, 400-418. 
Duronio, M. A., and Loessin, B. A. "Effective Business Practices in Fund Raising." In D. F. Burlingame and L. J. Hulse (eds.), Taking Fund Raising Seriously. San Francisco: Jossey-Bass, 1991.

Frank, R. H. "What Price the Moral High Ground?" Southern Economic Journal, 1996, 63, 1-17.

Gerhart, B. "Gender Differences in Current and Starting Salaries: The Role of Performance, College Major, and Job Title." Industrial and Labor Relations Review, 1990, 43, 418-443.

Gibelman, M. "The Nonprofit Sector and Gender Discrimination: A Preliminary Investigation into the Glass Ceiling." Nonprofit Management and Leadership, 2000, 10, 251-269.

Gomez-Mejia, L. G. "Executive Compensation: A Reassessment and a Future Research Agenda." In G. Ferris (ed.), Research in Personnel and Human Resources Management. Greenwich, Conn.: JAI Press, 1994.

Gose, B. "Incentive Pay Helps Keep Some Top Fund Raisers on the Job." Chronicle of Philanthropy, Dec. 4, 2002. Retrieved Aug. 9, 2005, from http://www.philanthropy.com/jobs/2002/12/12/20021212356099.htm.

Gray, S. R., and Benson, P. G. "Determinants of Executive Compensation in Small Business Development Centers." Nonprofit Management and Leadership, 2003, 13(3), 213-227.

Groshen, E. L. "The Structure of the Female/Male Wage Differential: Is It Who You Are, What You Do, or Where You Work?" Journal of Human Resources, 1991, 26, 457-472.

GuideStar. "Gender, Geography, and Nonprofit Compensation." Williamsburg, Va.: Philanthropic Research, Oct. 2005.

Hallock, K. "Compensation in Nonprofit Organizations." Research in Personnel and Human Resource Management, 2000, 19, 243-294.

Hallock, K. F. "Managerial Pay and Governance in American Nonprofits." Industrial Relations, 2002a, 41, 377-406.

Hallock, K. R. "The Gender Pay and Employment Gaps for Top Managers in U.S. Nonprofits." Working paper, University of Illinois, 2002b.

Handy, F., and Katz, E. "The Wage Differential Between Nonprofit Institutions and Corporations: Getting More by Paying Less?" Journal of Comparative Economics, 1998, 26, 246-261.

Hansmann, H. "The Role of Nonprofit Enterprise." Yale Law Journal, 1980, 89, 835-901.

Harris, M. M., Gilbreath, B., and Sunday, J. A. "Why Are Women Paid Less Than Men, But Given Higher Raises?" Journal of Business and Psychology, 2002, 16, 499-514.

Harrison, B. J. "Is Percentage-Based Compensation Unethical?" Fund Raising Management, Dec. 1995, pp. 26-29.

Johnston, D., and Rudney, G. "Characteristics of Workers in Nonprofit Organizations." Monthly Labor Review, July 1987, pp. 28-33.

Knoke, D. "Associations and Interest Groups." Annual Review of Sociology, 1986, 12, 1-21. 
Leete, L. "Whither the Nonprofit Wage Differential? Estimates from the 1990 Census." Journal of Labor Economics, 2001, 19, 136-170.

Lewin, T. "Women Profit Less Than Men in the Nonprofit World, Too." New York Times, June 3, 2001, p. 26.

Lipman, H. "Charities Pay Women Less Than Men, Study Finds." Chronicle of Philanthropy, July 25, 2002. Retrieved Aug. 17, 2002, from http://philanthropy.com/premium/articles/v14/i19/19004001.htm.

Mohan, N., and Ruggiero, J. "Compensation Differences Between Male and Female CEOs for Publicly Traded Firms: A Nonparametric Analysis." Journal of the Operational Research Society, 2003, 54, 1242-1248.

Oster, S. M. "Executive Compensation in the Nonprofit Sector." Nonprofit Management and Leadership, 1998, 8, 207-221.

Payton, R. L., Russo, H. A., and Tempel, E. R. "Toward a Philosophy of Fund Raising." In D. F. Burlingame and L. J. Hulse (eds.), Taking Fund Raising Seriously. San Francisco: Jossey-Bass, 1991.

Pink, G. H., and, Leatt, P. "Are Managers Compensated for Hospital Financial Performance?" Health Care Management Review, 1991, 16, 37-45.

Preston, A. E. "The Nonprofit Worker in a For-Profit World." Journal of Labor Economics, 1989, 7, 438-463.

Preston, A. E. "Compensation in Nonprofit Organizations." In D. R. Young (ed.), Effective Economic Decision Making in Nonprofit Organizations. New York: Foundation Center, 2004.

Renner, C., Rives, J. M., and Bowlin, W. F. "The Significance of Gender in Explaining Senior Executive Pay Variations: An Exploratory Study." Journal of Managerial Issues, 2002, 14, 331-345.

Rocco, J. E. "Making Incentive Compensation Plans Work in Nonprofit Organizations." Nonprofit World, 1991, 9, 13-15.

Rocco, J. E. "Latest Trends in Nonprofit Compensation: How to Attract the Brightest People." Nonprofit World, 1992, 10, 20-22.

Roomkin, M. J., and Weisbrod, B. S. "Managerial Compensation and Incentives in For-Profit and Nonprofit Hospitals." Journal of Law, Economics and Organization, 1999, 15, 750-781.

Rose, S. J., and Hartmann, H. I. "Still a Man's Labor Market: The Long-Term Earnings Gap." Washington, D.C.: Institute for Women's Policy Research, 2004.

Ruhm, C. J., and Borkoski, C. "Compensation in the Nonprofit Sector." Journal of Human Resources, 2003, 38, 992-1021.

Schwinn, E., and Wilhelm, I. "Nonprofit CEOs See Salaries Rise: Pay Raises Beat Inflation Rate Despite Economic Squeeze." Chronicle of Philanthropy, Oct. 2, 2003. Retrieved Aug. 9, 2005, from http:// www.philanthropy.com/free/articles/v15/i24/24002701.htm.

Sczudlo, W. "Motivation: Mission or Money?" Advancing Philanthropy, Sept.-Oct. 2003, pp. 30-32.

Steinberg, R. "Profits and Incentive Compensation in Nonprofit Firms." Nonprofit Management and Leadership, 1990, 1, 137-151.

Steinberg, R., and Jacobs, J. A. "Pay Equity in Nonprofit Organizations: Making Women Work Visible." In T. Odendahl and 
M. O'Neill (eds.), Women and Power in the Nonprofit Sector. San Francisco: Jossey-Bass, 1994.

Tifft, S. E. "Asking for a Fortune." Working Woman, Nov. 1992, pp. 66-94.

Tosi, H. L., Werner, S., Katz, J. P., and Gomez-Mejia, L. R. "How Much Does Performance Matter? A Meta-Analysis of CEO Pay Studies." Journal of Management, 2000, 26, 301-339.

Tschirhart, M. "Nonprofit Membership Associations." In W. W. Powell and R. Steinberg (eds.), The Nonprofit Sector: A Research Handbook. (2nd ed.) New Haven, Conn.: Yale University Press, 2006.

Weichselbaumer, D. "Is It Sex or Personality? The Impact of Sex Stereotypes on Discrimination in Applicant Selection." Eastern Economic Journal, 2004, 30, 159-186.

Weisbrod, B. A. "Nonprofit and Proprietary Sector Behavior: Wage Differential Among Lawyers." Journal of Labor Economics, 1983, 1, 246-263.

Weisbrod, B. "Toward a Theory of the Voluntary Nonprofit Sector in a Three Sector Economy." In S. Rose-Ackerman (ed.), The Economics of Nonprofit Institutions: Studies in Structure and Policy. New York: Oxford University Press, 1986.

Weisbrod, B. A. The Nonprofit Economy. Cambridge, Mass.: Harvard University Press, 1988.

Werner, S., Konopaske, R., and Gemeinhardt, G. "The Effects of United Way Membership on Employee Pay in Nonprofit Organizations." Nonprofit Management and Leadership, 2000, 11, 35-48.

Williams, S. "Gender Inequities Persist in CEO Compensation." Association Management, 2003, 55, 22.

Wood, R. G., Corcoran, M. E., and Courant, P. N. "Pay Differences Among the Highly Paid: The Male-Female Earnings Gap in Lawyers' Salaries." Journal of Labor Economics, 1993, 11, 417-441.

Ye, M., and Manzo, P. B. "Gender Compensation Disparity Among Executives: Examining California Nonprofits." Paper presented at the ARNOVA Conference, Los Angeles, Nov. 2004.

Young, D., and Steinberg, R. Economics for Nonprofit Managers. New York: Foundation Center, 1995. 
nm1184_06-435-464.axd 4/8/08 9:27 PM Page 464 